\title{
PENYULUHAN BAHAYA MEROKOK BAGI REMAJA DENGAN LAYANAN PENGUASAAN KONTEN DI PONDOK PESANTREN SENTOT ALI BASYA KOTA BENGKULU
}

\section{COUNSELING ON THE DANGERS OF SMOKING FOR TEENS WITH CONTENT MASTERY SERVICES AT SENTOT ALI BASYA ISLAMIC BOARDING SCHOOL IN BENGKULU CITY}

\author{
Oleh: \\ Vira Afriyati, Arsyadani Mishbahuddin \\ Jurusan Ilmu pendidikan FKIP Universitas Bengkulu \\ Email:vira_afriyati@unib.ac.id./haidardani01@gmail.com
}

\begin{abstract}
Smoking is one problem that is difficult to solve. And it has become a national, and even international problem. This becomes difficult, because it deals with many factors that trigger each other, so that it seems as if it has become a vicious circle. Smoking must be stopped because it causes health problems, resulting in death, therefore smoking must be stopped as a prevention effort as early as possible. As one part of the element of education, Counseling Guidance has a function of understanding. Through content mastery services, students are given an understanding of how dangerous smoking is to their health. This service is done by using content mastery services. From the results of the implementation of this activity there was an increase in students' understanding of the dangers of smoking and the desire to stop smoking. So that it can be concluded that this activity had a positive impact on santri.
\end{abstract}

Keywords: Smoking, content mastery services.

\section{PENDAHULUAN}

Masa remaja yaitu masa di mana terjadinya kelabilan jiwa karena telah memasuki fase dari anak-anak menuju fase dewasa. Pada umumnya masa remaja yaitu antara 12-21 tahun. Pada perkembangan manusia, terdapat tuntutan-tuntutan psikologis yang harus dipenuhi, jika tidak maka akan menimbulkan dampak yang berkelanjutan. Remaja pun juga seperti itu, jika tuntutan itu tidak dipenuhi, maka akan menimbulkan dampak yang signifikan dalam perkembangannya menuju kedewasaan.

Kebiasaan merokok telah menjadi budaya di berbagai bangsa di belahan dunia. Mayoritas perokok di seluruh dunia ini $47 \%$ adalah populasi pria sedangkan $12 \%$ adalah populasi wanita dengan berbagai kategori umur. Berbagai alasan orang merokok beraneka ragam, di kalangan remaja ini adalah faktor gengsi dan agar disebut "jagoan". Adapun berbagai alasan dan faktor penyebab untuk merokok di atas biasanya kalah, seandainya beradu argumen dengan pakar yang ahli tentang potensi berbahaya atas apa ditimbulkan dari kebiasaan merokok baik bagi dirinya sendiri, orang lain dan lingkungan.

Fenomena merokok di kalangan ramaja usia sekolah bukan pemandangan asing lagi. Data Kementerian Kesehatan (Kemenkes) 2017 menyebut sebanyak 2-3 dari 10 anak Indonesia usia 15-19 tahun merupakan perokok aktif. Jumlah perokok usia anak (di bawah 
usia 18 tahun) juga meningkat dari 7,2\% pada 2013 menjadi 8,8\% pada 2016. Fakta yang juga mengkhawatirkan, yaitu 34,71\% anak usia 5-17 tahun diketahui menghisap lebih dari 70 batang rokok perminggu (SUSENAS, 2016). 33\% siswa laki-laki dan $17 \%$ dari seluruh jumlah siswa di Indonesia, merokok untuk pertama kali pada usia di bawah 13 tahun, umumnya di bangku sekolah dasar (Kemenkes, 2016). Selain itu, sekitar $49 \%$ atau 43 juta dari total 87 juta anak di Indonesia telah terpapar asap rokok (perokok pasif). Sekitar 11,4 juta atau $27 \%$ diantaranya, merupakan anak berusia di bawah 5 tahun atau balita (Kemenkes, 2016) (www.suara.com).

Merokok merupakan salah satu masalah yang sulit dipecahkan. Apalagi sudah menjadi masalah nasional, dan bahkan internasional. Hal ini menjadi sulit, karena berkaitan dengan banyak faktor yang saling memicu, sehingga seolah- olah sudah menjadi lingkaran setan. Ditinjau dari segi kesehatan, merokok harus dihentikan karena menyebabkan kanker dan penyumbatan pembuluh darah yang mengakibatkan kematian, oleh karena itu merokok harus dihentikan sebagai usaha pencegahan sedini mungkin. Terlebih diketahui bahwa sebagian santri yang berada di Pondok Pesantren Sentot Ali Basya banyak yang merokok ketika selesai jam belajar atau sedang berada di asrama, padahal usia mereka tergolong remaja dan masih sekolah MTs dan MA. Ternyata hal demikian selama ini sudah dianggap biasa oleh sebagian dikalangan santri.

Untuk itu, perlu adanya pihak-pihak yang melakukan upaya pemberian pemahaman, pencegahan serta pengentasan terhadap anak-anak remaja. Sejalan dengan itu, bimbingan dan konseling sebagai salah satu bagian penting dalam sebuah sekolah perlu melakukan sesuatu. Dan dalam layanan konseling sesuai dengan Permendikbud No 111 tahun 2014 layanan penguasaan konten yaitu layanan bimbingan dan konseling yang membantu peserta didik menguasai konten tertentu, terutama kompetensi dan atau kebiasaan dalam melakukan, berbuat atau mengerjakan sesuatu yang berguna dalam kehidupan di sekolah/madrasah, keluarga, dan masyarakat sesuai dengan tuntutan kemajuan dan berkarakter cerdas yang terpuji, sesuai dengan potensi dan peminatan dirinya. Layanan penguasaan konten adalah layanan bantuan kepada individu (sendiri-sendiri ataupun dalam kelompok) untuk menguasai kemampuan atau kompetensi tertentu melalui kegiatan belajar (Prayitno, 2012). Jadi menurut Prayitno di dalam layanan penguasaan konten harus terdapat suatu konten atau kemampuan atau kompetensi tertentu yang dibelajarkan kepada siswa dan diharapkan siswa mampu menguasai konten tersebut secara matang.

Tujuan dari pemberian layanan penguasaan konten terbagi menjadi dua. Pertama tujuan umum layanan penguasaan konten adalah dikuasainya suatu konten tertentu. Penguasaan konten ini perlu bagi individu untuk menambah wawasan dan pemahaman, mengarahkan penilaian dan sikap,menguasai cara-cara kebiasaan tertentu untuk memenuhi kebutuhannya dan mengatasi masalah-masalahnya. Kedua tujuan khusus penguasaan konten dapat dilihat pertama dari kepentingan individu atau klien mempelajarinya, dan kedua isi konten itu sendiri (Prayitno, 2012).

\section{METODE KEGIATAN}

\section{Upaya mengatasi rokok pada remaja}

Merokok di sekolah yang dilakukan siswa kini semakin banyak, itu dikarenakan siswa yang satu mengajak siswa yang lainnya atau dikarenakan oleh faktor pergaulan. Oleh karena itu para guru lebih ketat lagi dalam melakukan pengawasan dengan mengelilingi tempat-tempat yang sering dijadikan tempat merokok. 
Selain itu juga melakukan peringatan yang lebih tegas lagi agar para pelanggar khususnya perokok jera dan tidak melakukan hal tersebut lagi baik di sekolah maupun di luar sekolah. Jika karena kecanduan, maka tips yang harus dilakukan adalah:

a. Pikirkanlah hal-hal yang menyenangkan yang akan terjadi pada tubuh ketika masa krisis karena berhenti merokok (biasanya 1,5 sampai 2 minggu).

b. Minumlah banyak air putih, makan banyak sayur dan buah-buahan setiap kali timbul keinginan untuk merokok.

c. Berbicara atau berkomunikasilah dengan orang lain dan tetaplah menyibukkan diri

d. Berolahraga yang menyenagkan dan disukai secara teratur dan terukur.

e. Pijatlah daerah punggung dan leher, lalu tariklah napas dalam-dalam.

Jika karena ketergantungan, maka putuskan semua hubungan antara rokok dan kebiasaan-kebiasaan yang sering dilakukan dengan tips berikut ini:

1. Jika ingin merasakan rokok di tangan, bermainlah dengan barang-barang lain seperti pensil, pena, atau membaca buku.

2. Jika ada keinginan untuk menyalakan rokok, jauhkan rokok dari jangkauan dan buanglah korek api.

3. Jika biasa merokok sesudah makan, segeralah bangkit dari duduk setelah makan, gosok gihi dan pergilah berjalan atau lakukan kegiatan yang membuat lupa pada rokok.

4. Jika merokok disertai dengan minum kopi, maka ganilah kopi dengan jus buah, dll.

5. Jika merokok untuk menenangkan diri, maka cobalah untuk mengingat bahaya merokok dapat mengakibatkan penyakit jantung, paru-paru, kanker, stroke, keguguran, dll.

Berikut ini beberapa tips yang perlu diperhatikan:

a. Tanyalah pada diri sendiri, apakah ada teman, saudara, atau tetangga yang menderita salah satu penyakit di atas. Bayangkan jika penyakit tersebut menyerang diri kita sendiri.

b. Jika keinginan untuk merokok sangat kuat, lakukanlah olahraga ringan seperti berjalan-jalan atau lakukan kegiatan yang menjadi kegemaran atau hobi Anda.

c. Jika berpikir bahwa merokok dapat membuat kita menjadi tenang atau nyaman, maka katakanlah dan akuilah secara jujur bahwa rokok tidak mungkin bisa mengatasi masalah yang ada.

d. Untuk mengatasi masalah ini, perlu melibatkan keluarga, teman, dan saudara untuk membantu mengalihkan perhatian dari rokok.

e. Jika ingin berhenti merokok harus menetapkan tindakan yang akan dipilih atau perilaku apa yang paling mudah diubah berkaitan dengan situasi merokok.

f. Buatlah pernyataan untuk berhenti merokok, kemudian bacalah pernyataan tentang niat berhenti merokok di depan teman atau saudara atau anggota keluarga yang akan menjadi pengingat agar keinginan berhenti merokok tercapai.

\section{Pendekatan Teknik Layanan Penguasaan Konten}

\section{a. Konten}

Konten merupakan isi layanan penguasaan konten, yaitu satu unit materi yang menjadi pokok isi bahasan atau materi latihan yang dikembangkan oleh guru pembimbing dan diikuti oleh peserta didik. Layanan penguasaan konten dapat diangkat dari bidangbidang pelayanan konseling, menurut Prayitno dan Erman (2004), yaitu bidang-bidang: 1) Pengembangan kehidupan pribadi; 2) Pengembangan kemampuan hubungan social; 3) 
Pengembangan kegiatan belajar; 4) Pengembangan perancanaan karier; 5)Pengembangan kehidupan berkeluarga; 6) Pengembangan kehidupan beragama.

Berkenaan dengan semua bidang pelayanan yang dimaksudkan itu dapat diambil dan dikembangkan berbagai hal yang kemudian dikemas menjadi topik atau pokok bahasan, bahan latihan, dan atau isi kegiatan yang diikuti oleh peserta pelayanan. Konten dalam layanan penguasaan konten itu sangat bervariasi, baik dalam bentuk, materi, maupun acuanya. Acuan yang dimaksud itu dapat terkait dengan tugas-tugas perkembangan peserta didik, kegiatan dan hasil belajar siswa, nilai, moral dan tata krama pergaulan, peraturan dan disiplin sekolah, bakat, minat, dan arah karir, ibadah keagamaan, kehidupan dalam keluarga, dan secara khusus permasalahan peserta didik.

\section{b. Pendekatan}

Layanan penguasaan konten pada umumnya diselenggarakan secara langsung (bersifat direktif) dan tatap muka, dengan format klasikal, kelompok, atau individual. Dalam hal ini guru pembimbing menegakkan dua nilai proses pembelajaran menurut Prayitno dan Erman (2004), nilai porose tersebut yaitu:

1. High-touch

Yaitu sentuhan-sentuhan tingkat tinggi yang mengenai aspek-aspek kepribadian dan kemanusiaan peserta layanan (terutama aspek-aspek afektif, semangat, sikap, nilai, dan moral), malaui implementasi oleh guru pembimbing: a). Kewibawaan, b). Kasih sayang dan kelembutan, c). Keteladanan, d). Pemberiaan penguatan, e) Tindakan tegas yang mendidik

2. High-tech

Yaitu teknologi tingkat tinggi untuk menjamin kualitas penguasaan konten, melalui implementasi oleh guru pembimbing: a). Materi pembelajaran, b) metode pembelajaran, c) alat bantu pembelajaran, e) penilaiaan hasil pembelajaran

3. Pengusaan konten

Pelaksanan layanan penguasaan konten terlebih dahulu harus diawali dengan pemahaman dan penguasaan konten oleh guru pembimbing. Hal ini sesuai dengan pernyataan guru Prayitno dan Erman (2004) yaitu pertama-tama guru pembimbing menguasai konten dengan berbagai aspeknya yang akan menjadi isi layanan. Makin kuat penguasaan konten ini akan semakin meningkatkan kewibawaan guru pembimbing dimata peserta layanan.

\section{c. Teknik}

Setelah konten dikuasai, guru pembimbing membawa konten tersebut kearena layanan penguasaan konten berbagai teknik dapat digunakan menurut Prayitno dan Erman (2004) yaitu:

1. Penyajian yaitu guru pembimbing menyajikan materi pokok konten setelah para peserta disiapkan sebagaimana mestinya.

2. Tanya jawab dan diskusi yaitu guru pembimbing mendorong partisipasi aktif dan langsung para peserta, untuk memantapkan wawasan dan pemahaman peserta, serta berbagai kaitan dalam segenap aspek-aspek konten.

3. Kegiatan lanjutan yaitu sesuai dengan penekanan aspek tertentu dari konten dilakukan berbagai kegiatan lanjutan.kegiatan ini dapt berupa: diskusi kelompok, penugasan dan latihan terbatas, survey lapangan, percobaan (termasuk kegiatan laboratorium) dan latihan tindakan (dalam rangka pengubahan tingkah laku).

\section{d. Media pembelajaran}

Untuk memperkuat proses pembelajaran dalam rangka penguasaan konten, guru pembimbing dapat menggunakan beragai perangkat keras dan perangkat lunak media 
pembelajaran, meliputi alat peraga. Media tulis dan grafis, peralatan dan program elektronik. Penggunaan media ini akan meningkatkan aplikasi high-tech dalam layanan penguasaan konten.

\section{e. Penilaiaan}

Secara umum penilaiaan terhadap hasil layanan penguasaan konten diorentasikan kepada diprolehnya UCA (understanding - pemahaman baru, comfort- perasaan lega, dan action- rencana kegiatan pasca layanan). Secara khusus, penilaian hasil layanan khusus, penilaiaan hasil layanan penguasaan konten ditekankan kepada penguasaan peserta atau peserta didik atas aspek-aspek konten yang dipelajari.

Menurut Prayitno dan Erman (2004), penilaiaan layanan dapat diselenggarakan dalam tiga tahap yaitu sebagai berikut:

1) Penilaiaan segera (laiseg), penilaiaan yang diadakan segera menjelang diakhirinya setiap kegiatan layanan.

2) Penilaian jangka pendek (laijapen), penilaiaan yang diadakan beberapa waktu (satu minggu sampai satu bulan) setelah kegiatan layanan.

3) Penilaian jangka panjang (laijapang), penilaiaan yang diadakan setelah satu bulan atau lebih pasca layanan.

Laijapang dapat mencakup penilaiaan terhadap konten untuk sejumlah sesi layanan penguasaan konten, khususnya untuk rangkaiaan konten-konten yang berkelanjutan. Format penilaiaan dapat tertulis ataupun lisan.

\section{HASIL DAN PEMBAHASAN}

Hasil dan luaran dari kegiatan yang dilaksanakan pada hari Sabtu, tanggal 21 dan 28 September 2018 adalah sebagai berikut:

1. Kegiatan di ikuti oleh 49 orang siswa.

2. Sebanyak $80 \%$ siswa sudah mengerti dan memahami tentang bahaya merokok dan cara berhenti serta mengajak orang lain untuk berhenti merokok, hal ini diperoleh dari hasil pengamatan langsung ketika kegiatan berlangsung. Hal ini juga tampak dari sesi tanya jawab yang dilakukan bersama anak-anak pondok pesantren.

3. Terkirim artikel pengabdian ke jurnal Dharma Raflesia Universitas Bengkulu

Kegiatan pengabdian kepada masyarakat yang dilakukan, yaitu memberikan pertama, pemahaman tentang bahaya merokok, kedua pencegahan bagi para pesrta yang tidak merokok, serta pengentasan bagaimana cara berhenti merokok dan mengajak orang di sekitar untuk berenti merokok pada santri di Pondok Pesantren Ali Basya Kota Bengkulu. Kegiatan ini dilaksanakan dua kali pertemuan yaitu pada tanggal 21 dan 28 September 2018.

Tahap awal kegiatan pengabdian kepada masyarakat adalah dengan melakukan tanya jawab tentang pengetahuan santri terhadap asal muasal rokok, penyebab mereka ikut merokok, dimana saja mereka merokok, berapa banyak yang dihabiskan sehari, bahaya rokok yang mereka ketahui. Hal ini dilakukan untuk melihat dan mengukur pengetahuan para santri tentang rokok. Ternyata pada awal pertemuan ini santri masih banyak yang belum paham betul akan bahaya secara kesehatan dan bahwa merokok bisa dihentikan .

Tahap kedua adalah pelaksanaan kegiatan sosialisasi dengan memaparkan sejarah adanya rokok, penyebab banyak remaja menjadi sasaran pabrik rokok, dampak merokok bagi lingkungan dan diri si perokok serta cara berhenti dan mengajak orang di sekitar 
untuk berhenti merokok. . Pada tahap ini antusias peserta sangat luar biasa, banyak sekali hal-hal yang selama ini belum mereka ketahui seperti mereka memang diincar oleh pabrik rokok untuk melariskan produknya. Setelah selesai pemaparan pada tahap ke dua ini, kemudian dilanjutkan diskusi dan tanya jawab dengan para santri. Tim Pengabdian juga melakukan evaluasi dengan memberikan pertanyaan secara langsung kepada para santri. Ternyata antusias untuk menjawab pertanyaan sangat luar biasa, sehingga mereka berebut untuk saling menjawab. Maka dari sini sudah terlihat bahwa apa yang disampaikan pada materi pertama tentang bahaya merokok dan lain-lain mulai dipahami.

Tahap ketiga dalam kegiatan ini adalah memberikan permainan-permainan yang memicu mereka untuk bergerak aktif. Sehinga mereka bisa lebih semangat dalam mencoba mengurangi kebiasaan negatif merokok. Karena dengan bermain kadang-kadang anak-anak lebih paham. Ini juga mengurangi terlalu banyaknya materi yang di sampaikan di setiap pertemuan.

\section{KESIMPULAN DAN SARAN}

\section{Kesimpulan}

Berdasarkan hasil observasi dapat disimpulkan:

1. Sebanyak $80 \%$ siswa sudah mengerti dan memahami tentang rokok.

2. Santri memiliki pengetahuan dan pemahaman tentang tentang seluk beluk rokok dan zat racun yang dikandungnya.

3. Santri memiliki pengetahuan dan pemahaman tentang seberapa besar dampak rokok bagi kesehatan tubuh.

\section{Saran}

1. Perlunya bimbingan dan pengawasan dari orangtua dan guru/pengawan asrama terhadap lingkungan pergaulan anak. Teman bermain serta kebiasaan mereka ketika sedang berkumpul.

2. Orangtua dan Guru dapat bekerjasama untuk membantu anak dalam mengisi waktu luang dengan mengikuti kegiatan yang bermanfaat seperti ekstrakulikuler yang ada di pesantren, sehingga energy anak tersalurkan pada tempat yang tepat.

\section{DAFTAR PUSTAKA}

https://www.suara.com/health/2018/. Jumlah Perokok Anak Meningkat, Ini Kata Menteri Yohana, oleh Ade Indra Kusuma dan Vessy Dwirika Frizona.

Permendikbud 111 tahun 2014, tentang bimbingan dan konseling. Prayitno, 2012, Jenis Layanan dan Kegiatan Pendukung Konseling, Padang : FIP-UNP. Prayitno., Erman., Amti, 2004, Dasar-Dasar Bimbingan dan Konseling, Jakarta : Rineka Cipta. 